\title{
Intestinal cellular localization of PCNA protein and CYP I A mRNA in Atlantic salmon Salmo salar L. exposed to a model toxicant Monica Sanden* and Pål A Olsvik
}

\author{
Address: National Institute of Nutrition and Seafood Research (NIFES), N-5817 Bergen, Norway \\ Email: Monica Sanden* - monica.sanden@nifes.no; Pål A Olsvik - pal.olsvik@nifes.no \\ * Corresponding author
}

Published: 23 March 2009

BMC Physiology 2009, 9:3 doi:10.1186/1472-6793-9-3
Received: 15 October 2008

Accepted: 23 March 2009

This article is available from: http://www.biomedcentral.com/l472-6793/9/3

(c) 2009 Sanden and Olsvik; licensee BioMed Central Ltd.

This is an Open Access article distributed under the terms of the Creative Commons Attribution License (http://creativecommons.org/licenses/by/2.0), which permits unrestricted use, distribution, and reproduction in any medium, provided the original work is properly cited.

\begin{abstract}
Background: The aim of the study was to examine the intestinal cellular localization of proliferating cell nuclear antigen (PCNA) and cytochrome P450 AI (CYPIA) expression in Atlantic salmon Salmo salar $\mathrm{L}$. exposed to a model toxicant. The stress response was induced by intraperitoneal injection of four salmon with a single dose $(50 \mathrm{mg} / \mathrm{kg})$ of the CYPIA inducer $\beta$ naphthoflavone (BNF) and intestinal tissue (mid and distal intestine; MI and DI) was sampled seven days later. Samples for histology and gene transcription analysis were collected from four exposed fish and four control fish. PCNA was assessed by immunohistochemistry, CYPIA mRNA was studied by in situ hybridization (ISH) and finally the transcription of five genes was quantified by realtime quantitative RT-PCR (real-time RT-PCR); two detoxifying genes (CYPIA and glutathione Stransferase; GST), a stress marker gene (heat shock protein 70; HSP70), PCNA and a gene marker of apoptosis (caspase 6A).

Results: PCNA protein and CYPIA mRNA were successfully localized in the intestinal cells (MI) of both experimental groups. At the cellular level, BNF significantly lowered intestinal cell proliferation and increased the CYPIA mRNA levels compared to the control group. The real-time RT-PCR data, which showed an increased mRNA expression both in the MI and DI of I39- and 62fold, respectively, confirmed the increased cellular CYPIA mRNA levels detected using ISH. HSP70 expression was also up-regulated in the exposed fish. The other examined genes did not show any differential regulation in the experimental fish group.

Conclusion: This study showed that CYPIA mRNA had a specific intestinal cellular transcription pattern in Atlantic salmon exposed to BNF. At the cellular level CYPIA mRNA expression was always observed at or around the cell nucleus close to the basolateral cell membrane and at the tissue level CYPIA mRNA expression was most frequently observed in the basal and apex area of the intestinal folds. Taken together, a link between the intestinal detoxification system (CYPIA) and cell renewal system (PCNA) is indicated with these two processes being inversely correlated in BNF exposed fish.
\end{abstract}

\section{Background}

The intestinal tract is a complex organ with functions related to digestion, absorption, endocrine regulation of digestion and metabolism, water and electrolyte balance and immunity [1]. As the aquatic environment is continuously contaminated with foreign organic chemicals it is 
essential to know how these compounds affect molecular and cellular mechanisms in the intestinal tract. Under normal homeostatic circumstances, new cells that are formed at the basal area of the intestinal folds and during cell differentiation cells migrate to the apex area where they are shred off during the process of apoptosis [2]. The interplay between cellular proliferation, differentiation and regulated cell death is essential for the maintenance of the intestinal tract [3].

In the fish intestine it has been demonstrated that homeostasis and structural features may be disturbed by dietary factors [4-8], dietary restriction [9-11] and exposure to xenobiotics $[6,12,13]$. Inhibition or stimulation of proliferation could be the first sign of abnormality in the intestinal tract and is often used as an early warning biomarker $[5,14,15]$. Cell proliferation can be investigated by immunohistochemical staining of the proliferating cell nuclear antigen (PCNA) [16] and by real-time RT-PCR analysis of PCNA transcription levels. PCNA is a $36 \mathrm{kD}$ nuclear protein required for DNA synthesis and repair, and is closely associated with DNA polymerase in the S-phase of the cell cycle. Previous studies have described intestinal cell renewal in teleosts, showing that proliferating cells are found at the base of the intestinal fold $[17,18]$. However, it has also been found that a definite zone of proliferation in fish is difficult to identify $[11,19]$.

Although the initialization of the apoptotic process varies widely between species, tissues and conditions, the intracellular apoptotic process is highly conserved. Caspases, which are the executioners of apoptosis, can be divided into two classes, the initiators and the effectors. The examined protein in the present study, caspase 6A, belongs to the effector caspases, and its expression is tightly regulated in the apoptotic pathway [20]

Components of the monooxygenase system (including CYP1A) are found along the whole length of the fish intestinal tract, but the highest activity is found in the proximal portions [21]. Along with CYP1A, heat shock protein 70 (HSP70) is one of the most studied proteins known to respond to a number of external stressors in fish [22-25]. HSP70 is an indicator of stress or exposure to toxicants [26] and evidence shows that it also protects cells from apoptosis [27].

In the present study $\beta$-naphthoflavone (BNF), an aryl hydrocarbon receptor (AhR) agonist and a known model toxicant, was intraperitoneal (i.p) injected into the experimental fish. The effects of BNF have been reported in several fish species and are well known [28-30]. The relationship between AhR, the cell renewal system [31] and several biotransformation enzymes, including cyto- chrome P450 1A (CYP1A) [25,32] and glutathione Stransferases (GSTs) [33] is well documented. However, little information is available on the cellular relationship and localization of the intestinal integrity parameter (PCNA protein) and the toxicology parameter (CYP1A mRNA) in a stressed intestine.

The aim of the study was to examine the cellular localization of CYP1A mRNA and PCNA protein in a stressinduced intestine. Tissues from the middle part of the intestine (MI) and the distal part of the intestine (DI) were sampled for analysis (Fig. 1). To confirm that the model toxicant successfully induced a stress reaction in the intestine, the expression of five genes encoding proteins involved in cellular response to stressors were examined; CYP1A, HSP70, GST, PCNA and caspase 6A by real-time RT-PCR. The histological parameters PCNA protein and CYP1A mRNA, were only examined in the MI since previous observations indicate a higher metabolic capacity in the proximal intestine of fish compared to the distal parts $[10,11,18]$.

\section{Results}

A single dose of $\beta$-naphthoflavone (BNF) significantly decreased the intestinal cell proliferation in the mid intestine (MI). Fish exposed to BNF had a significantly lower density (\%) of PCNA-positive cells compared to fish in the control group (t-test: \% PCNA, $\mathrm{p}<0.03)$. Exposed fish had a PCNA index of $19.8 \pm 4.5$ (mean \pm SD) compared to the PCNA index of $27.3 \pm 4.1$ (mean \pm SD) in the control group (only for the MI). The relative quantification of PCNA positive cells confirmed the visual differences between the two experimental groups (Fig. 2). For both groups proliferating cells were observed in the basal area of the MI folds with only a few PCNA stained cells located in the cell differentiation zone. For quantification, only strongly stained cells located in the basal area 15 cells from the middle basal area were considered. Fig. 2A shows a representative section of cell proliferation in fish from the control group. Several cells in the basal area are strongly stained and assumed to be in the S-phase of the cell cycle. Fig. 2B shows a representative section of cell proliferation in fish from the exposed group and only weak PCNA staining can be seen. Only a few cells were strongly stained in the examined sections and generally the proliferative compartment length (PCL) (not measured) was smaller compared to the PCL in the exposed group. A brief description of intestinal PCL measurements can be found in Bakke-McKellep et al. [8].

Since the effect of BNF on CYP1A expression (see next paragraph) was much stronger in the MI samples compared to the distal intestine (DI) tissue, histological evaluations were performed only on this part of the intestinal tract. 


\section{Distal intestine Mid intestine}

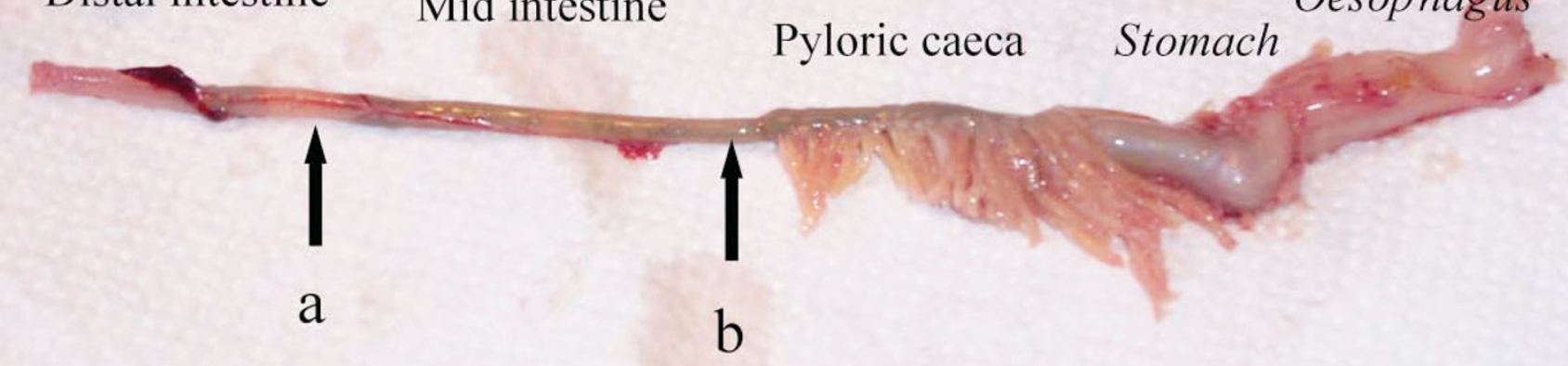

Gastrointestinal tract of Atlantic salmon, Salmo salar L.

\section{Figure I}

Gastrointestinal tract of Atlantic salmon ( $\approx 100$ grams) showing oesophagus, stomach, pyloric caeca, mid intestine (MI) and distal intestine (DI). A) Arrow showing where the DI samples were taken for gene expression B) Arrow showing where the $\mathrm{Ml}$ samples were taken for gene expression, immunohistochemistry and in situ hybridization.

Results of CYP1A mRNA transcription analysis by ISH in the MI can be seen in Fig. 3. In the exposed groups (Fig 3C) CYP1A mRNA was mainly localized in the basal area and apex area of the intestinal folds. Only weak staining could be seen in the cell differentiation zone of the MI fold. This expression pattern was the same in all fish exposed to BNF. CYP1A mRNA was mainly seen in one intestinal cell type, the enterocytes. Another interesting observation was the intracellular localization of the CYP1A transcript around the nucleus close to the basolateral membrane. CYP1A transcripts were only seen as weak and random staining in the cytoplasm close to the apical membrane. This feature was prominent both in the basal area and apex area of the MI fold. Results of CYP1A mRNA transcription in the control fish can be seen in Fig. $3 \mathrm{~B}$. In this group only weak signals could be seen and with no particular cellular or tissue expression pattern. Fig. 3A shows a representative example of a sense probe control.

BNF strongly induced CYP1A transcription in intestinal tissue of Atlantic salmon. CYP1A was 139-fold up-regulated in the MI (Fig. 4A) and 62-fold up-regulated in the DI (Fig. 5A) (t-test, $\mathrm{P}=0.028)$. HSP70 was significantly up-regulated in the DI (4.8-fold, t-test, $\mathrm{P}=0.028)$, and also up-regulated in the MI (3.3-fold, t-test, $\mathrm{P}=0.058)$. No significant differences in transcriptional levels were observed for the GST, PCNA and caspase 6A genes (Fig. 4 and 5).

\section{Discussion}

The intestinal mucosa provides an important site of metabolic defence against exposure to chemical contaminants, however the relationship of the intestinal integrity parameter (PCNA protein) and the toxicology parameter (CYP1A mRNA expression) is not well studied. We examined the influence of a single dose of a model toxicant $(\beta$ naphthoflavone; BNF) on the cellular localization of these two parameters together with the transcription of five genes in Atlantic salmon. Our experimental injection of BNF successfully induced a cellular stress response by strongly inducing CYP1A in both mid and distal intestine (MI and DI). The induction response of CYP1A can be quantitatively analysed by means of various molecular techniques (real-time RT-PCR, ISH) and by means of immunochemical approaches (ELISA, Western blotting).

The present study analysed intestinal mRNA CYP1A levels by real-time RT-PCR and by ISH and the real-time RT-PCR data showed that CYP1A was 139 fold (MI) and 62 fold (DI) up-regulated in the exposed animals similar to observations in the liver of the same fish [34]. The intestinal proximal distal gradient seen here is consistent with previously reported data for components belonging to the monooxygenase system [35]. The same picture was 


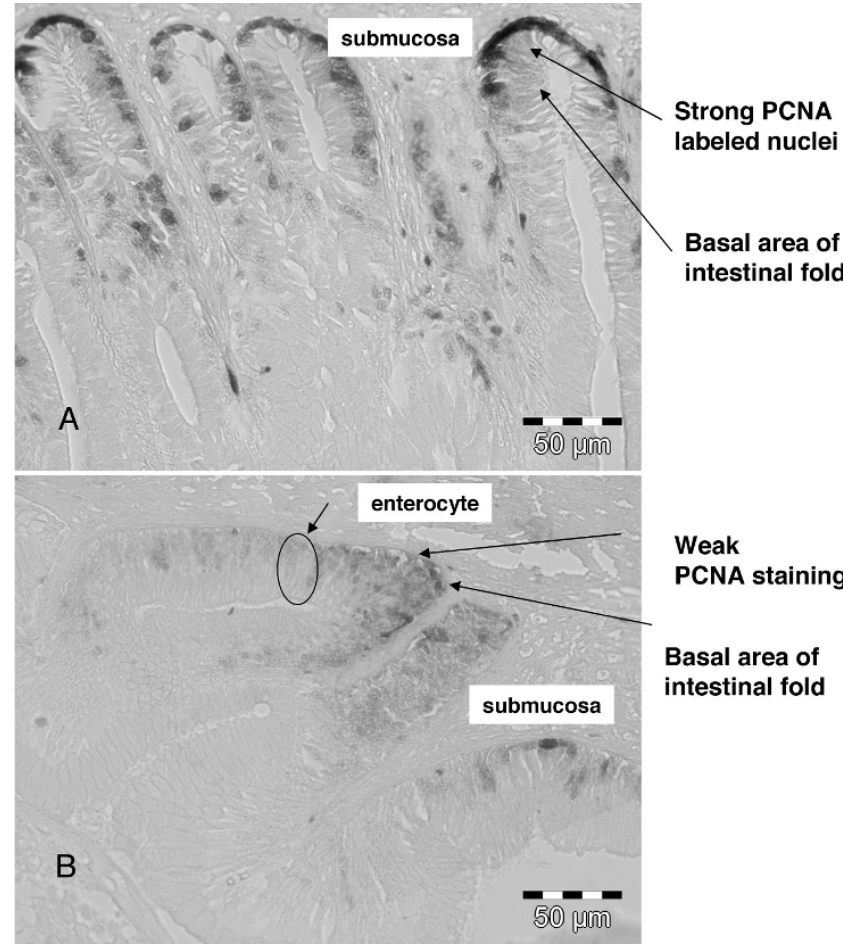

Figure 2

Light photomicrographs of PCNA labelled nuclei in the mid intestine (MI) of Atlantic salmon (A) In the control group, proliferating cells (PCNA) can be seen (strong black nuclear staining) in several cells in the basal area of the intestinal folds (B) In the treated group, proliferating cells (PCNA) can be seen (weak faint nuclear staining) only in a few cells in the basal area of the intestinal fold.

observed when CYP1A was localized within the MI tissue by ISH; exposed fish had a much higher CYP1A staining compared to the control fish (only weak and random CYP1A staining). Although the intestinal tissue is composed of several cell types, only the intestinal enterocytes gave strong CYP1A staining in the exposed group. Another interesting observation was the cellular localization of CYP1A mRNAs, CYP1A staining was always strongest at and around the nucleus where the endoplasmic reticulum (ER) is found. This observation corresponds nicely to the location of CYP1A in aquatic animals, which in many tissues is found in the ER and microsomes [36]. The pronounced CYP1A staining pattern may also indicate a quick translation into its nascent protein as CYP1A was never seen close to the apical membrane. The response pattern along the intestinal fold was common for all exposed fish and showed a characteristic strong staining in the basal area and in the apex area of the MI folds. This finding is supported by other studies on CYP1A protein induction in the intestinal epithelium [37].

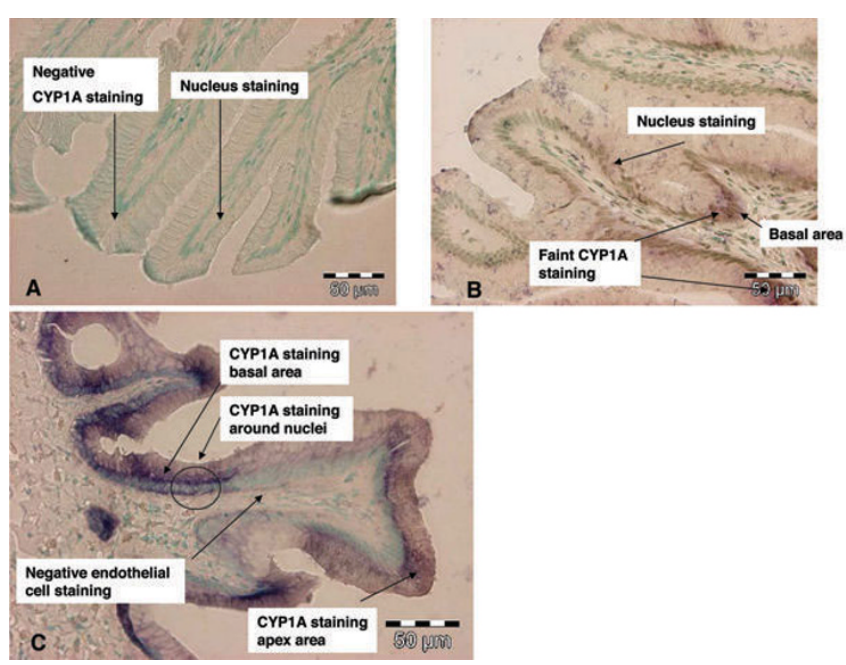

Figure 3

Light photomicrographs of CYP I A mRNA labelled mid intestine (MI) of Atlantic salmon (A) Negative control (sense). No CYPIA staining and only nuclear staining can be seen (B) Control group (antisense). CYPIA staining with faint and low mRNA levels especially in the basal area of the intestinal folds (C) Exposed group (antisense). CYPIA staining with strong and high mRNA levels especially in the basal area and the apex area of the intestinal fold. Inside the cells CYPIA are located at and around the nucleus. In the photographs CYPIA mRNA levels can be seen with a dark colour and all cell nuclei with a green staining. All pictures are stained with the nuclear stain; methyl green.

Endothelial cells are the first site of interaction with blood borne toxicants and one would expect biotransformation enzymes in these cells. However, in the present study CYP1A mRNA was only localized in the enterocytes of the intestinal mucosa epithelium. Other works report a sensitive induction of CYP1A in vascular endothelia of various teleost species, reported at the protein level [38-41]. However, previous studies have focused on protein expression, which may of course explain the observed differences on cellular expression patterns. Depending on cell type, mRNA half-lives are different, ranging from only minutes to several hours, and furthermore short lived mRNA's usually encode proteins of regulatory significance such as CYP1A [42]. The cellular pattern found in the present work only gives us a snapshot of the localization of CYP1A mRNA seven days after injection of BNF. The picture would probably look different if samples were taken at different time intervals after injection. Another explanation could be that BNF accumulates in the cytoplasm of the intestinal cells and continues to re-induce CYP1A in contrast to the effect of BNF in the endothelial cells. 
CYP1A

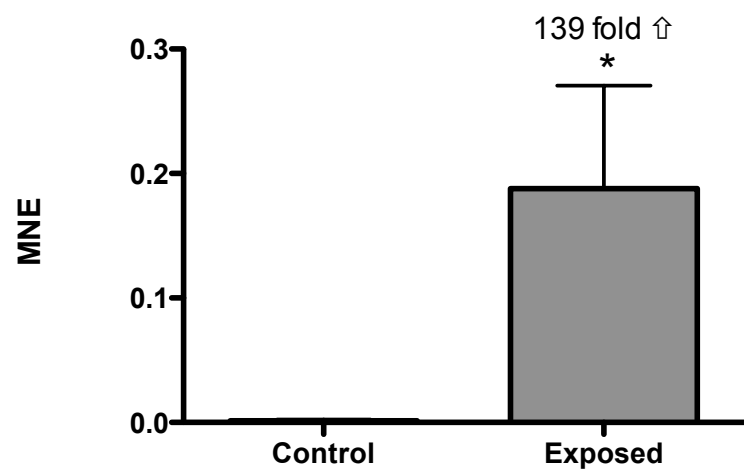

HSP70

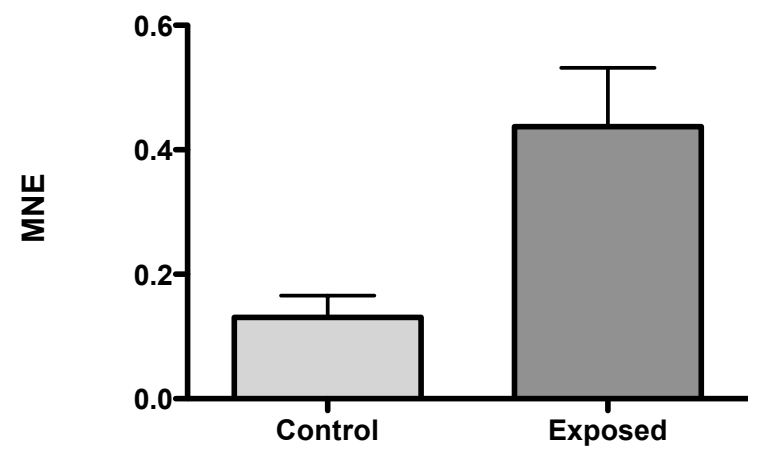

\section{PCNA}

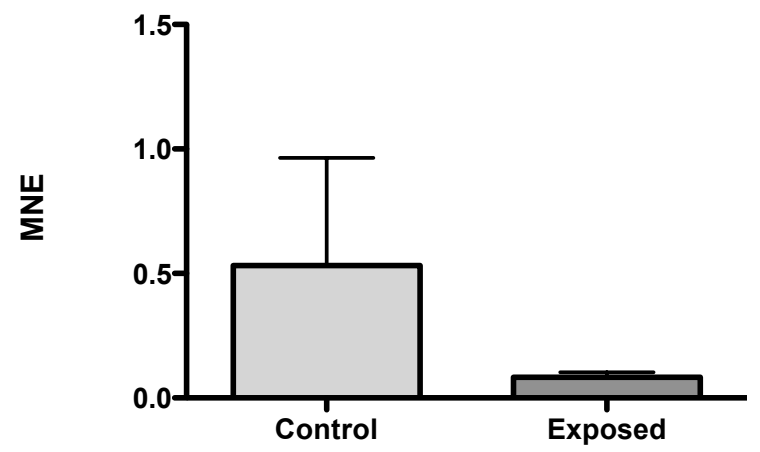

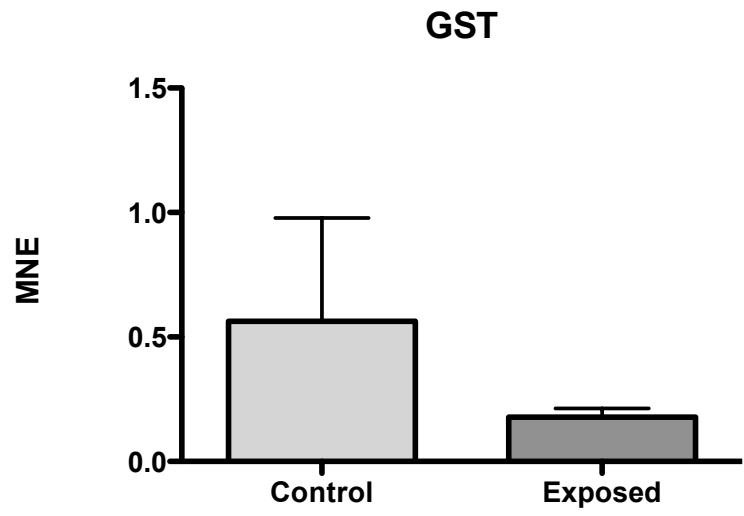

Caspase 6A

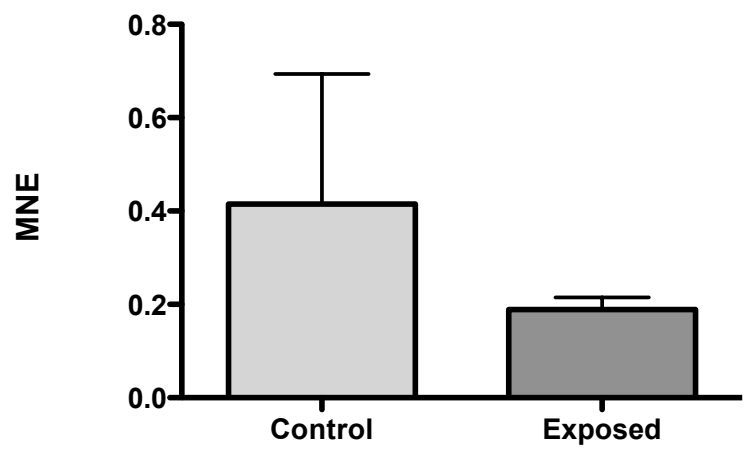

Figure 4

Mean normalized expression (MNE) of CYPIA, GST, HSP70, PCNA and caspase 6A in the mid intestine (MI) of Atlantic salmon exposed to BNF. An asterisk denotes a significant altered expression. Fold-change induction is shown in the figure. Mean \pm SEM. $n=4$. 


\section{CYP1A}

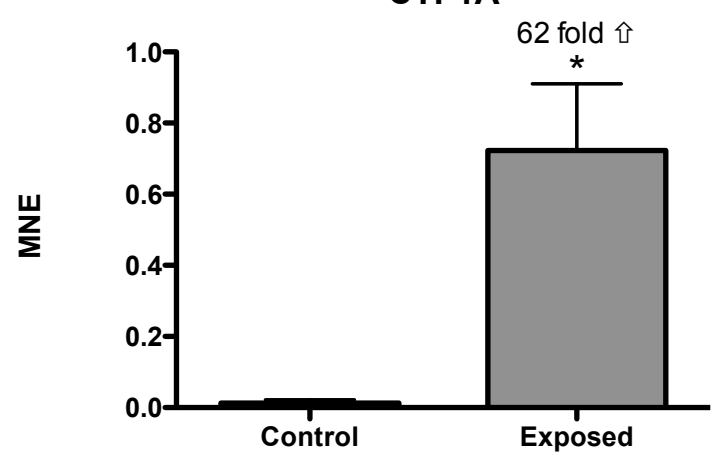

HSP70

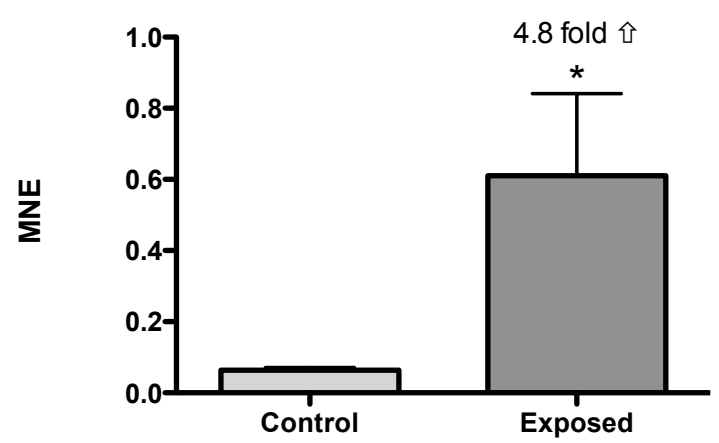

\section{PCNA}

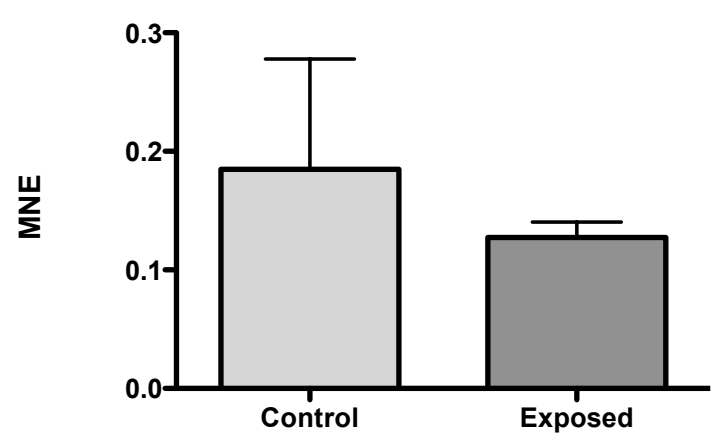

GST

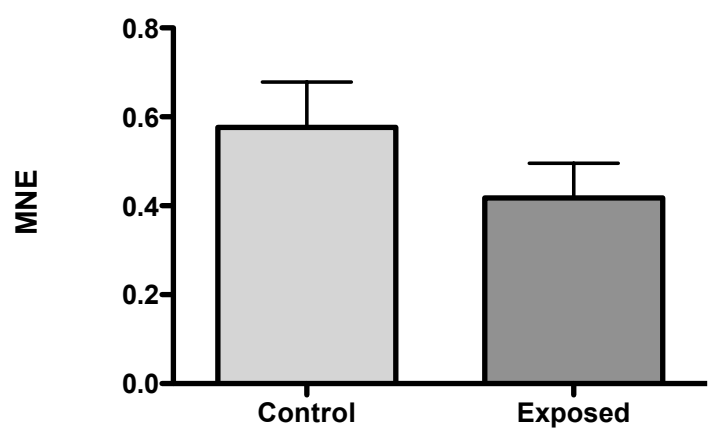

Caspase 6A

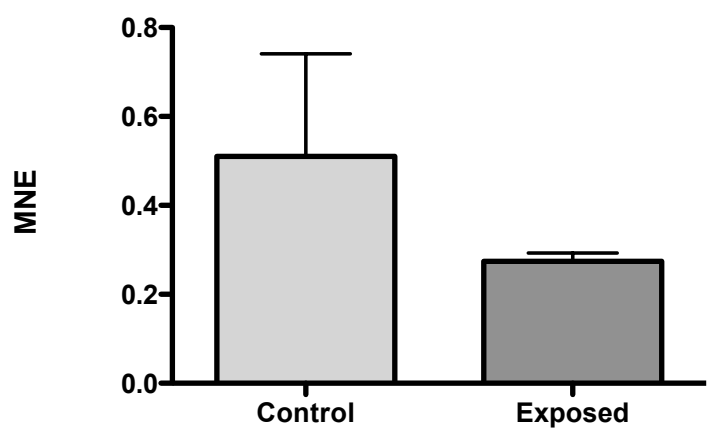

\section{Figure 5}

Mean normalized expression (MNE) of CYPIA, GST, HSP70, PCNA and caspase 6A in the distal intestine (DI) of Atlantic salmon exposed to BNF. An asterisk denotes a significant altered expression. Fold-change induction is shown in the figure. Mean \pm SEM. $n=4$.

Several examinations have reported a clear relationship between intestinal clearance of dietary toxicants and nutrient lipids (reviewed by [21], suggesting that intestinal accumulation of BNF could be related to a lack of feed (e.g. lipids) in the present experiment. BNF accumulation in the cell cytoplasm was also suggested in a similar work looking at the spatial transcription of CYP1A in liver [34]. The route of toxicant administration is also a factor that 
has given a different CYP1A organ/cellular induction pattern. Dietary exposure has a much stronger effect on the intestinal mucosa compared to aqueous exposure of the toxicants [43]. Intraperitoneal injection resembles a dietary exposure as both toxicants are primarily absorbed through the portal circulation [44].

This study also investigated the effects of BNF on glutathione S-transferase (GST; belonging to the $\pi$-class) which represents one of the phase II enzymes and is part of the AhR-gene battery. In the present study BNF exposure did not have the same effect on intestinal GST transcription level as compared to the strong CYP1A response. Modest induction of GST was also seen in hepatic tissue [33]. In the present study the transcription level of GST was slightly lower (not significant) in the exposed fish compared to the control group for both MI and DI sections.

Another possible stress indicator in fish is the heat shock proteins (HSPs) and the present experimental BNF exposure induced a small effect on intestinal (MI and DI) HSP70 mRNA levels. Along with the intestinal CYP1A induction, HSP70 gave the strongest intestinal stress response out of all investigated mRNA parameters. As most of the HSP genes do not contain introns, the mRNA is rapidly translated into proteins even within minutes of exposure to the stressor [22]. Based on our study, where samples were collected as long as 7 days after exposure, it is indicated that the BNF is continuously supplied from other organs (e.g. liver) to the intestinal cells, similarly to what we indicated previously for the BNF effect observed on intestinal CYP1A. A cytoprotective role of HSP70 after stress exposure is also suggested in the present study.

One aim of this work was to investigate co-ordinated responses of BNF exposure in the intestinal tract of Atlantic salmon. In cell cultures, AhR agonists can both inhibit and enhance cell proliferation, and AhR has been shown to regulate transcription of genes involved in growth and differentiation, including proteins involved in apoptosis (reviewed by [45]. In the present study intestinal cell proliferation (PCNA) was investigated both at the transcriptional level and at the protein level. Apoptosis was investigated at the transcriptional level using one of the effector caspases, caspase 6A. Only minor and random differences were observed in PCNA and caspase 6A at the transcriptional level. There was a tendency (not significant) however, especially in the MI samples, of a lower PCNA mRNA level in the exposed fish compared to the control group. A proximal-distal proliferative gradient was seen in the control group with the MI showing a relatively higher PCNA expression compared to the distal intestine, in line with observation in the mammalian intestine [46], and similar to the metabolic zonation of the teleost intestinal tract $[10,11]$.
Proliferating cells detected as strongly immunostained PCNA nuclei were mainly observed in the basal area of the MI folds for both exposed and control fish, but for the exposed fish a significant lower PCNA index was seen. This quantitative observation was supported visually with weak PCNA staining in the MI folds of exposed fish, indicating only a few cells being in the S-phase of the cell cycle. A similar response pattern (e.g. decrease in the intestinal proliferating cell pool) has been seen in the distal intestine of Atlantic salmon fed oxytetracycline [8] and in the MI of Atlantic salmon fed plant oils [7]. It is often seen that a down regulation of genes involved in cell proliferation (such as PCNA) often precedes morphological changes in the whole organ. This was observed in zebrafish exposed to TCDD (an AhR agonist) in which PCNA downregulation proceeded a decrease in heart growth $[47,48]$. Apart from the cellular localization of proliferating cells no histological evaluation on intestinal integrity was performed in the present work.

Another factor that may have affected the intestinal cell proliferation in the present study could be related to the feed restriction during the experiment. Before and after the BNF-injection fish were devoid of feed for more than 7 days and it has been observed in winter flounder, Pseudopleuronectes americanus, that the percentage of actively proliferating cells is substantially less in fasted fish (7 days) than in fed fish [11]. In mammalian intestine, fasting also results in reduced intestinal cell proliferation [49]. For the present investigation feeding the fish during the experimental period could have given larger effects at the transcriptional level between the exposed and control fish. It was interesting to see that the cellular immunostaining of PCNA was a more reliable and sensitive biomarker of cellular stress than PCNA mRNA levels.

In a study examining the spatial transcription of CYP1A in the liver of Atlantic salmon it was advised to always check how evenly target mRNAs are expressed in tissue sections and organs [34]. In the same study it was found that CYP1A mRNA levels were higher in the middle sections of the liver compared to the proximal and distal regions. As PCNA is not expressed in all cell types of the intestinal tract, sampling of bulk tissues (which is done for qPCR analysis) containing all cell types of the organ, usually cannot assign specific messages to particular cell types and could possible overlook differences at the cellular level.

\section{Conclusion}

This study shows a link between the intestinal detoxification system (CYP1A mRNA) and the cell renewal system (PCNA protein) with these two processes being inversely correlated. It appears that the intestinal cells are allocating all the energy to biotransformation of BNF and to minimizing the detrimental effects of BNF by repairing dam- 
aged proteins (HSP70 mRNA expression) instead of focusing on the maintenance of the intestinal system. Finally CYP1A mRNA showed a specific intestinal cellular and tissue transcriptional pattern when localized using in situ hybridization (ISH). At the cellular level CYP1A mRNA was always observed at or around the cell nucleus close to the basolateral membrane and at the tissue level CYP1A mRNA was found in the basal and apex area of the intestinal fold.

\section{Methods}

\section{Fish treatment}

This experiment was a follow-up study from one examining liver CYP1A expression [34]. A subset of the fish used in the original experiment were selected for further study of spatial PCNA protein and CYP1A mRNA expression in intestinal cells of Atlantic salmon exposed to $\beta$-naphthoflavone (BNF). The fish treatment will only be described briefly here as more details can be found in Olsvik et al. [34]. All fish were starved before $(24 \mathrm{~h})$ and during the experiment ( 7 days). On $21^{\text {st }}$ of April 2006, 8 individuals were randomly sampled and sedated by immersion in 50 $\mathrm{mg} / \mathrm{L}$ metacaine (Norsk Medisinaldepot, Oslo, Norway). Sedated fish were given an intraperitoneal injection of BNF (Sigma Chemical Co., St. Louis, MO, USA; $50 \mathrm{mg} / \mathrm{kg}$ body mass) dissolved in soybean oil $(10 \mathrm{mg} / \mathrm{ml})$ as described by Grosvik et al. [30]. Seven days after the exposure, 4 treated and 4 control salmon ( $50 \%$ of each sex) were anesthetized with metacaine and killed by a blow to the head before the post-gastric intestinal tract were dissected out. Only 4 treated and 4 control fish were chosen for further examination in the current examination, since we previously had documented the strong effect of BNF on CYP1A mRNA expression in other organs of the same fish [34] and since this mainly was a qualitative examination of PCNA activity and CYP1A expression in intestinal tissue.

\section{Tissue sampling}

The post-gastric intestinal tract was carefully dissected out and rinsed with phosphate buffered saline (PBS) from a total of 8 Atlantic salmon with an average body weight of $(\mathrm{n}=8$, mean $\pm S D, 396 \pm 65 \mathrm{~g})$ and body length $(\mathrm{n}=8$, mean $\pm \mathrm{SD}, 34.7 \pm 2.7 \mathrm{~g})$. Samples of mid intestine and distal intestine (MI and DI) were fixed in Bouin's solution and in phosphate-buffered formalin $(4 \%, \mathrm{pH} 7.2)$ overnight $(24 \mathrm{~h})$ before dehydration and paraffin embedding. Intestinal tissue for real-time RT-PCR were collected from the same intestinal samples and immediately frozen in liquefied nitrogen. Fig. 1 illustrates the intestinal sections used for tissue sampling.

\section{Histochemical analysis}

For histochemical detection of proliferating cell nuclear antigen (PCNA) a $10 \mathrm{~mm}$ sample of the MI were immediately sampled and placed into Bouin's solution (15:5:1 saturated picric acid:37\% formaldehyde in methanol:glacial acetic acid). After fixation, the samples were dehydrated in graded series of alcohol, equilibrated in xylene, embedded in paraffin and sectioned $(5 \mu \mathrm{m})$ using standard histological protocols. After mounting on poly-Llysine coated slides (Sigma-Aldrich, Oslo, Norway), sections were stained with a monoclonal antibody raised against rat PCNA using the procedure of Ortego et al. [16] and modified as described by Hemre et al. [14]. Briefly, after removing endogenous peroxidase activity with $1 \%$ $\mathrm{H}_{2} \mathrm{O}_{2}$ for $20 \mathrm{~min}$, antigen retrieval by temperature treatment in $1 \% \mathrm{ZnSO}_{4}(2 \mathrm{~min}$ at $780 \mathrm{~W}$ in microwave oven, cooling for $15 \mathrm{~min}$ ), and protein blocking in a tris buffered saline/triton (TBS/triton) solution (50 mM Tris, 150 $\mathrm{mM} \mathrm{NaCl}, 0.03 \%$ Triton $\mathrm{X}-100,0.5 \%$ bovine serum albumin and $0.5 \%$ powdered milk at $\mathrm{pH} 7.6$ ), the PCNA antibody (PC10, Chemicon, dilution 1:1000) was applied to the sections and incubated overnight at room temperature. After rinsing and protein blocking in a TBS/triton solution with $1 \%$ normal goat serum (Sigma, Poole, U.K), the sections were incubated for $1 \mathrm{~h}$ in biotinylated goatanti-mouse IgG (Amersham Pharmacia Biotech, Amesham, U.K) (1:200), and finally horseradish peroxidaseconjugated avidin biotin complex (ABC complex; DAKO, Glostrup, Denmark) was applied for $30 \mathrm{~min}$ (1:100). The peroxidase colour reaction was started by incubating in $0.04 \%(\mathrm{w} / \mathrm{v})$ diaminobenzidine (DAB; Sigma Aldrich, Oslo, Norway) Tris-HCl (50 mM, pH 7.6) after adding $0.015 \% \mathrm{H}_{2} \mathrm{O}_{2}$. The reaction was stopped after $24 \mathrm{~min}$ by rinsing in tap water. PCNA-positive intestinal cells were identified as described by Ortego et al. and Kilemade et al. $[16,50]$ and quantified according to Sanden et al. [5]. Six randomly selected intestinal folds were evaluated in each of three sections per fish and four fish per treatment group were examined. Only cells in the basal area of the intestinal fold and cells assumed to be in the S-phase of the cell cycle (strongly stained nuclei) were counted to avoid overestimating the proliferating cell pool [50].

\section{In situ hybridization (ISH)}

Antisense and sense RNA probes were synthesized employing a non-radioactive method using a DIG RNA Labeling Kit (Roche Applied Science, Oslo, Norway). A partial cDNA [GenBank:AF364076] was subcloned into the pSPT-18 vector, and then RNA probes were transcribed in vitro using SP6 RNA polymerase. Paraffin blocks of MI samples (fixed overnight in phosphate-buffered formalin $(4 \%, \mathrm{pH} 7.2))$ were stored in RNase-free sealed boxes at $4{ }^{\circ} \mathrm{C}$ until cutting $(5 \mu \mathrm{m})$, before mounted on Super Frost Plus slides (Bergman, Lillestrom, Norway) and dried overnight at $30^{\circ} \mathrm{C}$. All samples were coded to ensure unknown identity until examination was finished.

The ISH protocol used in this study is slightly modified from Ebbesson et al. [51]. Briefly slides were rehydrated in serial concentrations of alcohol. Sections were permeabi- 
lized using proteinase $\mathrm{K}(10 \mu \mathrm{g} / \mathrm{ml})$ in TrisHCl $(0.05 \mathrm{M}$, $\mathrm{pH} 7.5$ ) at RT for $5 \mathrm{~min}$, before post-fixation in $4 \%$ paraformaldehyde ( $\mathrm{pH} 7.5)$ for 10 min. Before prehybridization, slides were treated with $0.25 \%$ AA/TEA (acetic anhydride/triethanolamine) buffer (0.1 M, pH 8.0) for 10 min. Slides where then prehybridized in $10 \%$ dextran sulphate, $5 \times$ SSC (SDS sodium citrate buffer), $50 \%$ formamide, $5 \times$ Denhardts, $250 \mu \mathrm{g} / \mathrm{ml}$ tRNA, $500 \mu \mathrm{g}$ salmon sperm DNA for $2 \mathrm{~h}$ at RT in a moist chamber. Slides were then incubated with the DIG-AP cRNA probe $(500 \mathrm{ng} / \mathrm{ml}$ hyb buffer) in a moist chamber for $16 \mathrm{~h}$ at $67^{\circ} \mathrm{C}$. After the hybridization, slides were washed using the following protocol: $5 \times$ SSC at RT for $30 \mathrm{~min}, 30 \%$ formamide in 5 $\times$ SSC at $67^{\circ} \mathrm{C}$ for $15 \mathrm{~min}$, cooling to RT, before a final wash in $0.2 \times$ SSC at RT for $5 \mathrm{~min}$. To control the trueness of the hybridization and the probes, a brief RNase treatment was performed. Probes were then visualized by incubating the slides with a sheep anti-DIG (1:1500 in blocking solution; heat inactivated goat serum) solution at $8^{\circ} \mathrm{C}$ over night. The alkaline phosphatase reaction was performed by incubating the slides in reaction solution NBT/BCIP (Nitro-Blue Tetrazolium Chloride/5-Bromo-4Chloro-3'-Indolyphosphate p-Toluidine Salt) + Levamizole $0.3 \mathrm{mg} / \mathrm{ml}$ ) for $1.5 \mathrm{~h}$ at $\mathrm{RT}$. The colour reaction was stopped in a stop solution ( $10 \mathrm{mM}$ TrisHCl, $1 \mathrm{mM}$ EDTA, $0.9 \% \mathrm{NaCl}, \mathrm{pH} 8.0$ ). Sections were counterstained in methyl green (Sigma Chemical Co., St. Louis, MO, USA) for $7 \mathrm{~min}$ prior to quick dehydration, cleared in xylene, and mounted in entellan.

Sections stained for PCNA and CYP1A mRNA were examined with an Olympus BX51 light microscope (Olympus Hamburg, Germany) and micrographs obtained using an Olympus DP50 digital imaging system mounted on the microscope. Histological slides were qualitatively evaluated using the software cell*B 2006 (Olympus, Hamburg, Germany).

\section{RNA extraction, RNA quality and integrity}

Tissues were thoroughly homogenized before RNA extraction with zirconium beads ( $4 \mathrm{~mm}$ ) in a Retsch MM 301 homogenizer (Retsch GmbH, Haan, Germany). Total RNA was extracted using Trizol reagent (Invitrogen, Life
Technologies, Carlsbad, CA, USA), according to the manufacturer's instructions and stored in $100 \mu$ l RNase-free MilliQ $\mathrm{H}_{2} \mathrm{O}$. Genomic DNA was eliminated from the samples by DNase treatment according to the manufacturer's description (DNA-free, Ambion, Austin, TX, USA). The RNA was then stored at $-80^{\circ} \mathrm{C}$ before further processing. The quality of the RNA was assessed with the NanoDrop ${ }^{\circledR}$ ND-1000 UV-Vis Spectrophotometer (NanoDrop Technologies, Wilmington, DE, USA) and the Agilent 2100 Bioanalyzer (Agilent Technologies, Palo Alto, CA, USA). The RNA 6000 Nano LabChip ${ }^{\circledast}$ kit (Agilent Technologies, Palo Alto, CA, USA) was used to evaluate the integrity of the RNA. All samples had a RNA integrity number (RIN) of 7.0 or higher $(n=16$, mean $\pm S D, 8.7 \pm 0.7)$.

\section{Real-time quantitative RT-PCR}

PCR primer sequences used for quantification of the genes encoding $\beta$-actin, elongation factor 1 alpha $\left(E F 1 A_{B}\right)$, acidic ribosomal protein (ARP), CYP1A, GST $\pi$, PCNA, HSP70 and caspase 6A are shown in Table 1. For more detailed information on the PCR assays, see Olsvik et al. $[7,34]$. The primer pairs amplified PCR products between 59-121 basepairs (bp) long. The geNorm software was used to evaluate the stabilities of the three reference genes. A normalization factor based on all three examined reference genes ( $\beta$-actin, $E F 1 A_{B}$ and ARP) was used to calculate mean normalized expression (MNE) of the target genes [52]

\section{Statistics}

A simple t-test was used to compare differences in PCNA and apoptosis indices between the two groups of Atlantic salmon using the software Statistica TM, Release 4.5 (Statsoft, Inc., Tulsa, OK, USA 1993). The t-test was also used to analyze gene expression differences between the control and the BNF-exposed fish. A significance level of $\mathrm{P}$ $<0.05$ was used for all tests.

\section{Authors' contributions}

MS initiated the research, evaluated all the in situ hybridization, immunohistochemistry and histology work and also wrote the paper. PAO was responsible for the exposure experiment and did the quantitative real-time RT-

Table I: PCR primers and amplicon sizes of the reference and target genes used in the present study.

\begin{tabular}{lllc}
\hline Gene & Forward primer 5'-3' & Reverse primer 5'-3' & Product size (bp) \\
\hline Beta-actin & CCAAAGCCAACAGGGAGAA & AGGGACAACACTGCCTGGAT & 92 \\
EFIAB & TGCCCCTCCAGGATGTCTAC & CACGGCCCACAGGTACTG & 59 \\
ARP & TCATCCAATTGCTGGATGACTATC & CTTCCCACGCAAGGACAGA & 101 \\
CYPIA & TGGAGATCTTCCGGCACTCT & CAGGTGTCCTTGGGAATGGA & 101 \\
GST & ATTTTGGGACGGGCTGACA & CCTGGTGCTCTGCTCCAGTT & 81 \\
PCNA & CGTGGAGAGTATGGATTCGTCCCACG & CGCAGCGGTAAGAGTCGAAC & 80 \\
HSP70 & CCCCTGTCCCTGGGTATTG & CACCAGGCTGGTTGTCTGAGT & 121 \\
Caspase 6A & TGAGCCACGGAGAGAACGA & CCCACCAGGCTCTTACACTTG & 103 \\
\hline
\end{tabular}


PCR analysis and helped drafting those parts of the manuscript. Both authors read and approved the final manuscript.

\section{Acknowledgements}

This work was financially supported by the National Institute of Nutrition and Seafood Research (NIFES), Norway. The authors thank Hui-Shan Tung for performing the in situ hybridization analysis, Eva Mykkeltvedt for accomplishing the PCNA immunohistochemistry and Kay Kristoffer Lie for all help during the fish handling and practical work. Finally the authors would like to thank Øystein Sxle and Arne Duinker for valuable advice on microscope work and discussions regarding histological pictures.

\section{References}

I. Buddington RK, Krogdahl A, BakkeMcKellep AM: The intestines of carnivorous fish: structure and functions and the relations with diet. Acta Physiol Scand Suppl 1997, 638:67-80.

2. Hall PA, Coates PJ, Ansari B, Hopwood D: Regulation of cell number in the mammalian gastrointestinal-tract - the importance of apoptosis. J Cell Sci 1994, 107:3569-3577.

3. Potten $\mathrm{CS}$, Booth $\mathrm{C}$ : The role of radiation-induced and spontaneous apoptosis in the homeostasis of the gastrointestina epithelium: A brief review. Comp Biochem Physiol B-Biochem Mol Biol 1997, I I 8(3):473-478.

4. Moren M, Opstad I, Berntssen MHG, Infante JLZ, Hamre K: An optimum level of vitamin A supplements for Atlantic halibut (Hippoglossus hippoglossus L.) juveniles. Aquaculture 2004 , 235(I-4):587-599.

5. Sanden M, Berntssen MHG, Krogdahl A, Hemre GI, Bakke-McKellep AM: An examination of the intestinal tract of Atlantic salmon, Salmo salar L., parr fed different varieties of soy and maize. J Fish Dis 2005, 28(6):317-330.

6. Berntssen MHG, Aspholm OO, Hylland K, Bonga SEW, Lundebye AK Tissue metallothionein, apoptosis and cell proliferation responses in Atlantic salmon (Salmo salar L.) parr fed elevated dietary cadmium. Comp Biochem Physiol C-Toxicol Pharmacol 200I, I 28(3):299-310.

7. Olsvik PA, Torstensen BE, Berntssen MHG: Effects of complete replacement of fish oil with plant oil on gastrointestinal cell death, proliferation and transcription of eight genes' encoding proteins responding to cellular stress in Atlantic salmon Salmo salar L. J Fish Biol 2007, 7 I (2):550-568.

8. Bakke-McKellep AM, Penn MH, Salas PM, Refstie S, Sperstad S, Landsverk $T$, Ringo $E$, Krogdahl $A$ : Effects of dietary soyabean meal, inulin and oxytetracycline on intestinal microbiota and epithelial cell stress, apoptosis and proliferation in the teleost Atlantic salmon (Salmo salar L.). Brit J Nutr 2007, 97(4):699-7I 3.

9. Baeverfjord G, Krogdahl A: Development and regression of soybean meal induced enteritis in Atlantic salmon, Salmo sala L, distal intestine: A comparison with the intestines of fasted fish. J Fish Dis 1996, I9(5):375-387.

10. Mommsen TP, Osachoff HL, Elliott ME: Metabolic zonation in teleost gastrointestinal tract - Effects of fasting and cortisol in tilapia. I Comp Physiology B-Biochem Syst Environ Physiol 2003, 1 73(5):409-4I8.

II. Trier JS, Moxey PC: Epithelial-cell proliferation in the intestine of the winter flounder, Pseudopleuronectes-americanus. Cell Tissue Res 1980, 206(3):379-385.

12. Lundebye AK, Berntssen MHG, Bonga SEW, Maage A: Biochemica and physiological responses in Atlantic salmon (Salmo salar) following dietary exposure to copper and cadmium. Mar Poll Bull 1999, 39(1-I2): | 37-| 44

13. Ferrando S, Ferrando T, Girosi L, Mauceri A, Fasulo S, Tagliafierro G: Apoptosis, cell proliferation and serotonin immunoreactiv ity in gut of Liza aurata from natural heavy metal polluted environments: preliminary observations. Eur J Histochem 2005, 49(4):33I-340.

14. Hemre GI, Deng DF, Wilson RP, Berntssen MHG: Vitamin A metabolism and early biological responses in juvenile sunshine bass (Morone chrysops $\times$ M. saxatilis) fed graded levels of vitamin A. Aquaculture 2004, 235(I-4):645-658.
15. Ortego LS, Hawkins WE, Walker WW, Krol RM, Benson WH: Immunohistochemical detection of proliferating cell nuclear antigen (PCNA) in tissues of aquatic animals utilized in toxicity bioassays. Mar Environ Res 1995, 39( I-4):27I-273.

16. Ortego LS, Hawkins WE, Walker WW, Krol RM, Benson WH: Detection of proliferating cell nuclear antigen in tissues of 3 small fish species. Biotech Histochem 1994, 69(6):317-323.

17. Rombout J, Stroband HWJ, Tavernethiele J): Proliferation and differentiation of intestinal epithelial-cells during development of barbus-conchonius (Teleostei, Cyprinidae). Cell Tissue Res 1984, 236(I):207-216.

18. Stroband HW], Debets FMH: Ultrastructure and renewal of intestinal epithelium of juvenile grasscarp, Ctenopharyngodon-Idella-(Val). Cell Tissue Res 1978, I 87(2): |8I-200.

19. Kiss R, Delaunoit Y, Lenglet G, Danguy A: Autoradiographic investigations on cell-proliferation in the digestive mucosa of fishes. Acta Zool 1988, 69(4):225-230.

20. Shi YG: Mechanisms of caspase activation and inhibition during apoptosis. Mol Cell 2002, 9(3):459-470.

21. Van Veld PA: Absorption and metabolism of dietary xenobiotics by the intestine of fish. Rev Aquat Sci 1990, 2(2):185-203.

22. Iwama GK, Afonso LOB, Todgham A, Ackerman P, Nakano K: Are hsps suitable for indicating stressed states in fish? I Exp Biol 2004, 207(I): 15-19.

23. Basu N, Kennedy CJ, Hodson PV, Iwama GK: Altered stress responses in rainbow trout following a dietary administration of cortisol and beta-napthoflavone. Fish Physiol Biochem 200।, 25(2): I3|-|40.

24. Iwama GK, Thomas PT, Forsyth RHB, Vijayan MM: Heat shock protein expression in fish. Rev Fish Biol Fish I998, 8(I):35-56.

25. Goksoyr A, Forlin L: The cytochrome-P-450 system in fish, aquatic toxicology and environmental monitoring. Aquat Toxicol I992, 22(4):287-3। I

26. Feder ME, Hofmann GE: Heat-shock proteins, molecular chaperones, and the stress response: Evolutionary and ecological physiology. Ann Rev Physiol 1999, 6 I:243-282.

27. Mallouk Y, Vayssier-Taussat M, Bonventre JV, Polla BS: Heat shock protein 70 and ATP as partners in cell homeostasis (Review). Int J Mol Med I999, 4(5):463-474.

28. Di Bello D, Vaccaro E, Longo V, Regoli F, Nigro M, Benedetti M, Gervasi PG, Pretti C: Presence and inducibility by beta-naphthoflavone of CYPIAI, CYPIBI and phase II enzymes in Trematomus bernacchii, an Antarctic fish. Aquat Toxicol 2007. 84(I): 19-26.

29. Goksoyr A, Andersson T, Buhler DR, Stegeman J, Williams DE, Forlin $\mathrm{L}$ : Immunochemical cross-Reactivity of beta-naphthoflavone-inducible cytochrome P450 (P450ia) in liver-microsomes from different fish species and rat. Fish Physiol Biochem 1991, 9(I): I-13.

30. Grosvik BE, Larsen HE, Goksoyr A: Effects of piperonyl butoxide and beta-naphthoflavone on cytochrome P450 I A expression and activity in Atlantic salmon (Salmo salar L). Environ Toxicol Chem 1997, 16(3):415-423.

31. Hestermann EV, Stegeman JJ, Hahn ME: Relationships among the cell cycle, cell proliferation, and aryl hydrocarbon receptor expression in PLHC-I cells. Aquat Toxicol 2002, 58(3-4):20 I-2 I3.

32. Nebert DW, Roe AL, Dieter MZ, Solis WA, Yang Y, Dalton TP: Role of the aromatic hydrocarbon receptor and [Ah] gene battery in the oxidative stress response, cell cycle control, and apoptosis. Biochem Pharmacol 2000, 59(I):65-85.

33. Oost $R$ van der, Beyer J, Vermeulen NPE: Fish bioaccumulation and biomarkers in environmental risk assessment: a review. Environ Toxicol Pharmacol 2003, I3(2):57-149.

34. Olsvik $P$, Lie $K$, Saele $O$, Sanden $M$ : Spatial transcription of CYPIA in fish liver. BMC Physiol 2007, 7(I): I 2.

35. Van Veld PA, Stegeman J], Woodin BR, Patton JS, Lee RF: Induction of monooxygenase activity in the intestine of spot (Leiostomus xanthurus), a marine teleost, by dietary polycyclic aromatic hydrocarbons. Drug Metab Dispos 1988, I 6(5):659-665.

36. Stegeman J, Kloepper-Sams P: Cytochrome P-450 isozymes and monooxygenase activity in aquatic animals. Environ Health Perspect 1987, 7 I:87-95.

37. Sarasquete C, Segner H: Cytochrome P450 I A (CYPIA) in teleostean fishes. A review of immunohistochemical studies. SCi Tot Environ 2000, 247(2-3):313-332. 
38. Smolowitz RM, Hahn ME, Stegeman J]: Immunohistochemical localization of cytochrome-P-450la I induced by 3,3',4,4'-tetrachlorobiphenyl and by 2,3,7,8-tetrachlorodibenzoafuran in liver and extrahepatic tissues of the teleost stenotomus-chrysops (Scup). Drug Metab Dispos 199I, I 9(I): I I3-123.

39. Husoy AM, Myers MS, Willis ML, Collier TK, Celander M, Goksoyr A: Immunohistochemical localization of cypla-like and cyp3a-like isozymes in hepatic and extrahepatic tissues of Atlantic cod (Gadus-morhua L), a marine fish. Toxicol Appl Pharmacol 1994, I 29(2):294-308.

40. Stegeman JJ, Smolowitz RM, Hahn ME: Immunohistochemical localization of environmentally induced cytochromeP450ial in multiple organs of the marine teleost stenotomuschrysops (Scup). Toxicol Appl Pharmacol I 99I, I I 0(3):486-504.

4I. Huang YW, Stegeman J], Woodin BR, Karasov WH: Immunohistochemical localization of cytochrome P450 I A induced by 3,3 ',4,4 ',5-pentachlorobiphenyl (PCB I 26) in multiple organs of northern leopard frogs, Rana pipiens. Environ Toxicol Chem 200I, 20(1):191-197.

42. Meyer S, Temme C, Wahle E: Messenger RNA turnover in eukaryotes: Pathways and enzymes. Crit Rev Biochem Mol Biol 2004, 39(4): 197-216.

43. Van Veld PA, Vogelbein WK, Cochran MK, Goksøyr A, Stegeman J]: Route-specific cellular expression of cytochrome P450la (CYPIA) in fish (Fundulus heteroclitus) following exposure to aqueous and dietary benzo[a]pyrene. Toxicol Appl Pharmacol 1997, I 42(2):348-359.

44. Lukas G, Brindle SD, Greengar P: Route of absorption of intraperitoneally administered compounds. J Pharmacol Exp Ther 197I, I 78(3):562-566.

45. Kawajiri K, Fujii-Kuriyama Y: Cytochrome $\mathbf{P 4 5 0}$ gene regulation and physiological functions mediated by the aryl hydrocarbon receptor. Arch Biochem Biophys 2007, 464(2):207-2/2.

46. Kovacs L, Potten CS: Estimation of proliferative population size in stomach, jejunum and colon of dba-2 mice. Cell Tissue Kinet 1973, 6(2): 125-134.

47. Carney SA, Chen J, Burns CG, Xiong KM, Peterson RE, Heideman W: Aryl hydrocarbon receptor activation produces heart-specific transcriptional and toxic responses in developing zebrafish. Mol Pharmacol 2006, 70(2):549-56I.

48. Antkiewicz DS, Burns CG, Carney SA, Peterson RE, Heideman W: Heart malformation is an early response to TCDD in embryonic zebrafish. Toxicol Sci 2005, 84(2):368-377.

49. Altmann GG: Influence of starvation and refeeding on mucosal size and epithelial renewal in rat small-intestine. Am J Anat 1972, I33(4):391.

50. Kilemade M, Lyons-Alcantara M, Rose T, Fitzgerald R, Mothersill C: Rainbow trout primary epidermal cell proliferation as an indicator of aquatic toxicity: an in vitro/in vivo exposure comparison. Aquat Toxicol 2002, 60(I-2):43-59.

51. Ebbesson LE, Tipsmark CK, Holmqvist B, Nilsen T, Andersson E, Stefansson SO, Madsen SS: Nitric oxide synthase in the gill of Atlantic salmon: colocalization with and inhibition of $\mathrm{Na}+, \mathrm{K}+$ ATPase. J Exp Biol 2005, 208(6): I0I I-1017.

52. Vandesompele J, De Preter K, Pattyn F, Poppe B, Van Roy N, De Paepe A, Speleman F: Accurate normalization of real-time quantitative RT-PCR data by geometric averaging of multiple internal control genes. Genome Biol 2002, 3(7):research0034.003I-research0034.00II.
Publish with Bio Med Central and every scientist can read your work free of charge

"BioMed Central will be the most significant development for disseminating the results of biomedical research in our lifetime. "

Sir Paul Nurse, Cancer Research UK

Your research papers will be:

- available free of charge to the entire biomedical community

- peer reviewed and published immediately upon acceptance

- cited in PubMed and archived on PubMed Central

- yours - you keep the copyright

Submit your manuscript here:

http://www.biomedcentral.com/info/publishing_adv.asp
BioMedcentral 